\title{
Arsenic Addition to Soils from Airborne Coal Dust Originating at a Major Coal Shipping Terminal
}

\author{
William J. Bounds • Karen H. Johannesson
}

Received: 15 February 2007 / Accepted: 17 May 2007 / Published online: 21 June 2007

(C) Springer Science + Business Media B.V. 2007

\begin{abstract}
Soil samples were collected from Norfolk, Virginia in order to examine the extent of particulate coal, and associated arsenic (As) deposition to local soils. The particulate coal originates from the adjacent coal shipping terminal at the Lambert's Point Docks, which is the largest marine coal shipping terminal in the Northern Hemisphere. Particulate coal was separated from soil samples using heavy liquid (i.e., sodium polytungstate) extraction. Sand-sized coal separates isolated from the soil samples were subsequently digested using concentrated nitric and sulfuric acid, and analyzed for As by high-resolution inductively coupled plasma mass spectrometry (HR-ICP-MS). Selected total soil digests were also analyzed for As by HR-ICP-MS. Results indicate particulate coal ranges from less than $1 \%$ up to $\sim 20 \%$, by weight, of the soil samples analyzed. Arsenic concentrations in sand-sized particulate coal extracted from these sediments range from undetectable levels (i.e., $<3 \mathrm{ng} / \mathrm{kg}$ ) up to $17.4 \mathrm{mg} / \mathrm{kg}$, whereas total As concentrations in the
\end{abstract}

W. J. Bounds

Department of Ocean, Earth and Atmospheric Sciences, Old Dominion University,

Norfolk, VA 23529-0275, USA

K. H. Johannesson ( $\bowtie)$

Department of Earth and Environmental Sciences,

Tulane University,

New Orleans, LA 70118-5698, USA

e-mail: kjohanne@tulane.edu soils range from 3 to $30.5 \mathrm{mg} / \mathrm{kg}$. The data indicate that particulate coal originating at the Lambert's Point Docks is an additional source of As to local soils, especially sites proximal to the shipping terminal. Although the particulate coal itself likely poses only minor health hazards (if any), the environmental consequences of As transported with the particulate coal is not known.

Keywords Coal dust · Arsenic · Soils .

Airborne transport $\cdot$ Coal shipping terminal $\cdot$ Virginia

\section{Introduction}

Environmental concerns over the use of coal as a fossil fuel have commonly focused on the impact that mining, coal combustion, and the resultant fly ash has on environmental quality (e.g., Querol et al. 1991, 1992, 1999; Kizilshtein and Kholodkov 1999; Feng et al. 2000; Finkelman et al. 2002, 2006; Fuge 2005; Yudovich and Ketris 2005; Greb et al. 2006; Kolker et al. 2006). It is generally accepted, for example, that combustion of high-sulfur coal has contributed to the occurrence of acid rain and the consequent acidification of watersheds with low acid buffering capacity (Gupta 1999). Moreover, because fly ash generated from coal combustion can be enriched in many trace elements, including a number of potentially toxic trace elements such as arsenic (As), selenium (Se), cadmium $(\mathrm{Cd})$, chromium $(\mathrm{Cr})$, and mercury $(\mathrm{Hg})$, studies have 
examined the impact of trace element loading to the environment from fly ash fall-out (Eskenazy 1995; Querol et al. 1999; Fuge 2005; Mastalerz and Drobniak 2007). However, the environmental impact of and/or the potential human health issues arising from transport and shipping of coal, and subsequent inhalation of resulting "environmental" coal dust, have typically not been examined, although occupational inhalation has been extensively studied (e.g., coal workers' pneumoconiosis; Attfield et al. 1997, 1998; Finkelman et al. 2002; Centeno et al. 2005). Recent investigation of coal workers' pneumoconiosis (also known as black lung disease) suggests that finely disseminated pyrite grains within coat dust may be responsible for the inflammation of lung tissue that leads to development of lung fibrosis (Finkelman et al. 2006). Possible human health issues may also arise from inhalation of airborne "environmental" particulate coal owing to the fact that: (1) it can occur in size fractions (e.g., $\mathrm{PM}_{2.5} ;<2.5 \mu \mathrm{m}$ ) that are potentially hazardous (Zheng et al. 1999); and (2) because it may be enriched in pyrite and/or toxic trace elements such as As, $\mathrm{Hg}$, Se, Cd, and Cr (Eskenazy 1995; Smith et al. 1998; Querol et al. 1999; Finkelman et al. 2006).

The facility at the Lambert's Point Docks in Norfolk, Virginia (Fig. 1) is home to North America's largest coal shipping terminal in terms of total tonnage shipped. Specifically, more than 28 million tons of coal is shipped from Lambert's Point Docks annually (Dinsmore 1999). The method used to load coal from railroad cars to waiting ships involves overturning each coal-filled railroad car and dumping the coal onto a conveyor belt leading to the transport ship, where it is dumped again into the ship's hold. Owing to the nature of the process, the coal loading method generates "environmental" coal dust that is subsequently transported into nearby regions of Norfolk and Portsmouth, Virginia (Fig. 1). The Virginia Department of Environmental Quality (VDEQ (Virginia Department Environmental Quality) 2002) estimates that the coal pier at Lambert's Point released approximately 35 tons of particulate coal into the air during 2000 , although it is permitted to release up to 50 tons/ year. It is important to note that this permitted release
Fig. 1 Map showing the location of the study region in southeastern Virginia, USA (insert) and the locations of soil cores $\left(\mathrm{N}_{1}\right.$ through $\mathrm{N}_{8}, \mathrm{DS}_{1}$ and $\mathrm{DS}_{2}$ ), and surface soil samples $\left(\mathrm{S}_{1}\right.$ through $\mathrm{S}_{15}$ ), within the city of Norfolk, Virginia. Soil cores are shown as filled circles, whereas the surface sample locations are depicted as filled triangles. In addition, major railway lines $(++++)$ within the city of Norfolk are also shown along with a number of landmarks and neighborhoods. Old Dominion University is shown as ODU

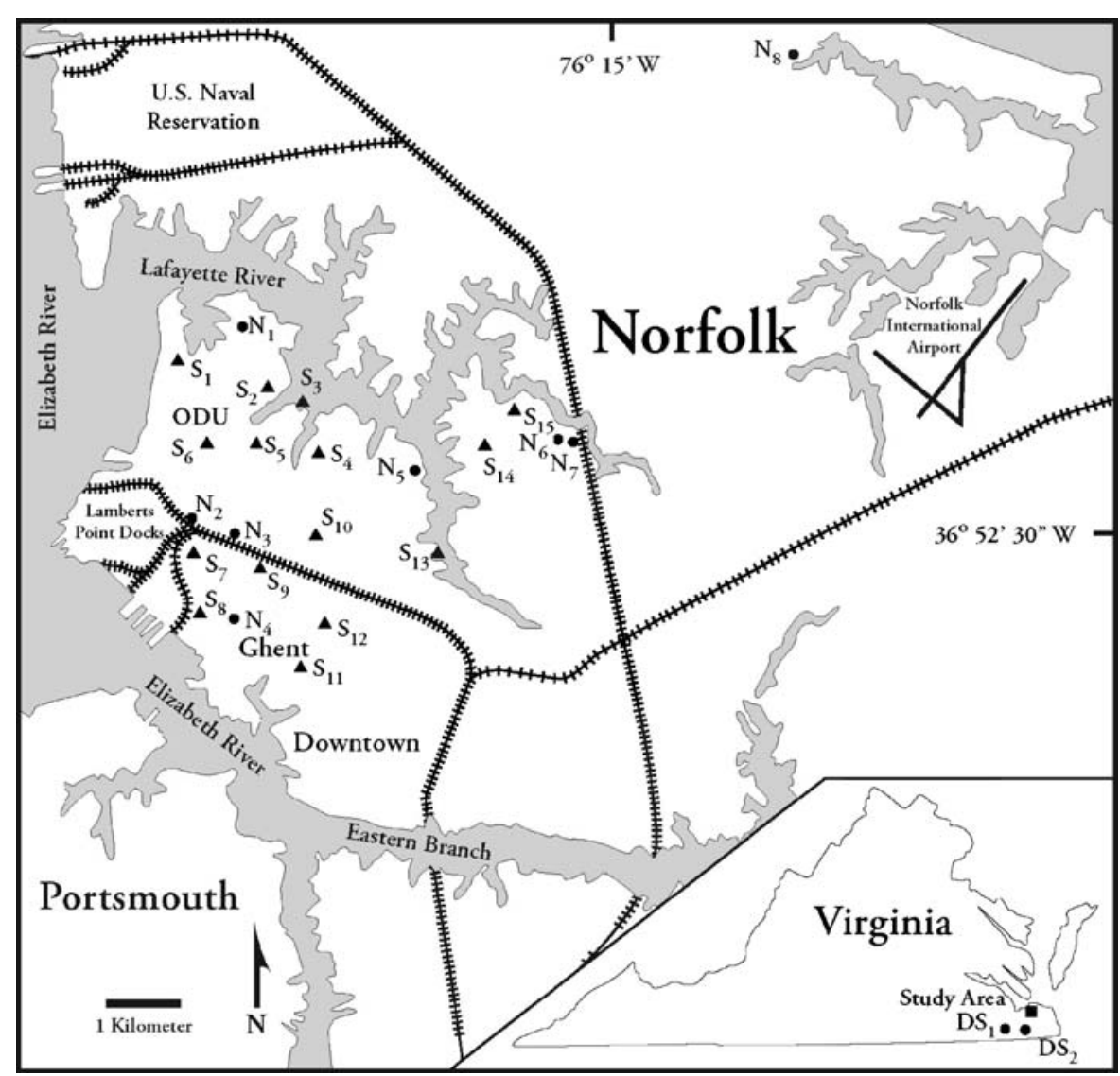


level for airborne coal dust was exceeded in 1999 (VDEQ 2002). Black, gritty veneers of what appears to be particulate coal coating objects (e.g., automobiles, window sills, plants, etc.) are common in both Norfolk and Portsmouth, Virginia, and anecdotal accounts suggest that such veneers are more prevalent in the West Ghent neighborhood of Norfolk, proximal to the Lambert's Point Docks. These thin coatings of probable coal dust suggest that airborne transport of coal dust from the Lambert's Point Docks is prevalent in the region. It should be mentioned that coal has also been transported into the study area via railways for reasons other than immediate export via the Lambert's Point Docks, including its use in household heating, storage for future shipment, and for burning in local coal-fired power plants.

\section{Study Site}

The study area is located in the southeast corner of the State of Virginia, on the east coast of the USA (Fig. 1). It is bounded by the Elizabeth River (i.e., tidal) along the west and south, the Lafayette River (also tidal) to the north, and thus includes a significant portion of the city of Norfolk, Virginia. The Lambert's Point Docks are located within Norfolk's city limits, along the Elizabeth River (Fig. 1). The region surrounding the docks is highly urbanized and characterized by low elevation and relatively flat terrain (Mixon et al. 1989).

The study region is underlain by the Tabb Formation, which was deposited during several high and low stands of sea-level during the Pleistocene (Mixon et al. 1989). The youngest member of the Tabb Formation is the Poquoson Member, which is a medium to coarse sand that grades upwards to clayey sands. The Poquoson Member is characterized by ridge and swale topography and achieves a maximum thickness of $4.6 \mathrm{~m}$ (Mixon et al. 1989). The Poquoson Member, however, is not exposed within the city of Norfolk (Mixon et al. 1989). Beneath the Poquoson Member is the Lynnhaven Member, which was deposited during a high stand of sea-level in the Pleistocene. The Lynnhaven Member is the chief member of the Tabb Formation that outcrops in the study region. The Lynnhaven Member consists of fine to coarse sands that grade upwards to sandy silts. It is cross-bedded at the base and has several channel cuts filled with clayey silt and organic material. The
Lynnhaven Member is an extensive surficial deposit that averages roughly $6 \mathrm{~m}$ in thickness and has a toe altitude of $5.4 \mathrm{~m}$ above mean sea-level (Mixon et al. 1989). Underlying the Lynnhaven Member is the Segfield Member, the oldest member of the Tabb Formation. The Segfield Member is composed of clayey sand that grades upwards to clayey silt. The Segfield Member also contains numerous channel fills at its base and is cross-bedded with clayey sands and clayey silts throughout. The Segfield Member ranges up to $15.2 \mathrm{~m}$ thick, and is assigned an approximate age of 71,000 years based on uranium-series dating of coral (Astrangia sp.) that occurs within the deposit (Mixon et al. 1989).

Soils in the study region are classified as urban soils (e.g., Brady and Weil 1996); hence, detailed descriptions of the soil have not been published. However, the soils in the study area closely resemble soil units common to southeastern Virginia including the Sassafras fine sandy loam, the Woodstown fine sandy loam, and the Keyport very fine sandy loam (Henry et al. 1959). All of these specific soils are found outside of the immediate study area, within the broader Hampton Roads region of southeastern Virginia. The Sassafras fine sandy loam is a friable, red/brown soil that grades to yellow/red, and is typically well drained. The Woodstown fine sandy loam is a moderately well drained friable soil that ranges from brown through yellow/brown to yellow in color. The Keyport very fine sandy loam is a moderately well drained soil that is characterized by high water holding capacity. The Keyport ranges from gray/brown to yellow/brown in color, and is mottled at depth (Henry et al. 1959).

The study area is characterized by warm humid summers, with a mean high temperature of $25.3^{\circ} \mathrm{C}$, and mild winters with an average low temperature of $6.5^{\circ} \mathrm{C}$ (Henry et al. 1959). The area's annual precipitation is $\sim 1,100 \mathrm{~mm} /$ year with the majority falling during the winter months (Henry et al. 1959). Prevailing winds for the area are from the west (Halpern et al. 2001).

\section{Materials and Methods}

\subsection{Sample Collection and Textural Classification}

Eight $32 \mathrm{~cm}$ deep soil cores were collected from the city of Norfolk, with seven of these cores from the 
immediate study area (labeled $\mathrm{N}_{i}$, where $i$ identifies the core number on Fig. 1). Two additional soil cores were also obtained from the Great Dismal Swamp outside of the immediate study (i.e., identified as $\mathrm{DS}_{i}$ on insert map of Virginia of Fig. 1). In addition, 15 surface soil samples, collected at a depth of $4 \mathrm{~cm}$, were obtained from the study region (marked $\mathrm{S}_{i}$ on Fig. 1). Sample locations were chosen primarily based on accessibility (i.e., public property or permission from title holder) and location relative to the Lambert's Point Docks. The soil cores from the Great Dismal Swamp (i.e., $\mathrm{DS}_{1}$ and $\mathrm{DS}_{2}$; Fig. 1) were collected as controls in order to determine the amount of particulate coal present in soils from regions we initially considered to be unaffected by deposition of particulate coal originating from the Lambert's Point Docks.

All soil core samples where collected to an approximate depth of $32 \mathrm{~cm}$ using a stainless steel hand auger. The auger was rinsed with ultra-pure Milli-Q water (18 M $\Omega$-cm) before commencing each coring. The soil samples were then extracted from the top of the auger and sampled at depth increments of $4.5 \mathrm{~cm}$ (i.e., $4 \mathrm{~cm}$ after accounting for soil expansion). Each soil sample was removed from the auger by scraping it off with a pre-cleaned (i.e., nitric acid rinsed) plastic spatula. Soil samples where then placed into pre-labeled, Ziplock ${ }^{\circledR}$-style polyethylene bags, returned to the laboratory, and subsequently dried in an oven before analysis.

The textural classification of each soil sample was determined (i.e., Bounds 2001) by adding $40 \mathrm{~g}$ aliquots of dried soil to a $10 \mathrm{~mL}$ solution of sodium hexametaphosphate in $100 \mathrm{ml}$ of Milli-Q water. The soil solution slurry was subsequently stirred to disperse the soil. After dispersal, the slurry was transferred to a $1,000 \mathrm{~mL}$ graduated cylinder, and filled to $700 \mathrm{~mL}$ with Milli-Q water (Bounds 2001). The slurry was shaken and allowed to settle for $40 \mathrm{~s}$ at which point a hydrometer reading was obtained. The hydrometer reading was used to determine the weight of the soil remaining in the water after the sand has settled out. Temperature was measured to correct the hydrometer reading. The same procedure was then repeated for the clay fraction, however; in this case, the hydrometer was read after $1.5 \mathrm{~h}$, which allows for both the sand and silt fraction to settle (e.g., see Gee and Bauder 1986, for method details, and Table 2 of Bounds 2001, for details concerning the distribution of sand-, silt-, and clay-sized particles in each soil sample). Briefly, the sand-sized fraction of the sediment cores ranges from 50 to $80 \mathrm{wt} . \%$. The siltsized fraction accounts for between 10 to $40 \mathrm{wt} . \%$, whereas the clay-sized fraction accounts for 9-20 wt.\% of each sample (Bounds 2001).

\subsection{Coal Particle Separation}

In order to extract the coal particles from the soil samples, $10 \mathrm{~g}$ of each soil was first placed into separate $150 \mathrm{~mL}$ beakers along with a solution consisting of $15 \mathrm{~mL}$ of sodium hypochlorite ("Baker Analyzed," reagent grade) in $100 \mathrm{~mL}$ of Milli-Q water (18 $\mathrm{M} \Omega-\mathrm{cm})$. It should be noted that all separations and sample handling were conducted in a class 100 laminar flow bench to minimize potential contamination from particles. The soil slurries were subsequently allowed to sit for a period of 1-5 days. The sodium hypochlorite procedure was chosen because Lewis and McConchie (1994) argue that it destroys the soil organic matter but does not affect coal particles. Indeed, no visible effects of the sodium hypochlorite on coal particles were observed in preliminary tests using crushed coal particles. Each soil sample was then wet sieved using sieves of $250 \mu \mathrm{m}$, followed by $63 \mu \mathrm{m}$, to separate the fine and coarse sand-size fractions from one another, and to separate the silt/ clay fraction. Sample aliquots that passed through each sieve were collected in $600 \mathrm{~mL}$ beakers. Upon completing the sieving, the size fractions (i.e., $>250 \mu \mathrm{m},>63 \mu \mathrm{m}$, and silt/clay fractions) were dried and weighed (Bounds 2001).

For the sand fraction of each soil sample, $25 \mathrm{~mL}$ of sodium polytungstate $\left(\rho=2.0 \mathrm{~g} / \mathrm{cm}^{3}\right.$; Fisher Scientific, ACS certified) was added in order to separate the coal from the rest of the soil. Sodium polytungstate was used because its density is greater than that of coal, but less than the density of the silicates and metal oxides in the soil. Consequently, the coal generally floats in the solution, whereas the silicates and metal oxides sink. Because coal particles containing finely disseminated pyrite could potentially sink in the heavy liquid solution, we cannot entirely rule out some loss of coal during the separation (see Section 4.2 below). After a period of $1 \mathrm{~h}$, the sodium polytungstate and suspended coal particles were decanted and filtered through a number 41 Whatman filter to separate the coal from the heavy liquid. The 
recovered coal particles were then washed with Milli-Q water, dried, and weighed (Bounds 2001).

Because only the $>63 \mu \mathrm{m}$ fraction of coal (i.e., sand-sized) was analyzed for As (see below), the $<63 \mu \mathrm{m}$ coal fraction (i.e., the silt/clay fraction) was subsequently subjected to digestion with hydrogen peroxide ("Baker Analyzed," reagent grade). The hydrogen peroxide attacks the coal but does not affect the silt or clay minerals (e.g., Lewis and McConchie 1994). Before the coal was digested with hydrogen peroxide, the weight of the silt/clay fraction was measured. The remaining silt/clay fraction was then dried and weighed, and the weight of the coal digested determined by difference (Bounds 2001). It should be noted that because the hydrogen peroxide may also dissolve sulfides, sulfates, and carbonates, the calculated difference gives a maximum value for the weight of the coal fraction.

\subsection{Arsenic Analysis}

As mentioned above, only the sand-sized coal fraction from each soil sample was analyzed for arsenic (As) in the recovered coal. Aliquots of the sand-sized coal fraction were crushed, reweighed, and then placed in $180 \mathrm{~mL}$ borosilicate glass digestion beakers along with $10 \mathrm{~mL}$ of concentrated Trace Metal Grade $\mathrm{HNO}_{3}$ (Fisher Scientific) and $1 \mathrm{~mL}$ of concentrated Trace Metal Grade $\mathrm{H}_{2} \mathrm{SO}_{4}$ (Fisher Scientific). The sample slurry was then allowed to sit covered overnight in a class 100 laminar flow hood. The coal samples were subsequently heated at $110^{\circ} \mathrm{C}$ on a hotplate for $4 \mathrm{~h}$. The samples were then removed from the hotplate and allowed to cool for $15 \mathrm{~min}$, after which $5 \mathrm{~mL}$ of $30 \%$ v/v ultra-pure $\mathrm{H}_{2} \mathrm{O}_{2}$ (Suprapur ${ }^{\circledR}$ grade) was added, and the samples returned to the hotplate for another $90 \mathrm{~min}$. The samples were then removed from the hotplate and $10 \mathrm{~mL}$ of Milli-Q water was added. At this point, the samples were allowed to cool, and were subsequently filtered through number 41 Whatman filter, to remove any remaining silicate, into $100 \mathrm{~mL}$ volumetric flasks, rinsed with Milli-Q water, and the volume made up to $100 \mathrm{~mL}$ with Milli-Q water. The samples were then transferred to pre-cleaned (i.e., acid-washed; Johannesson et al. 2004) high density polyethylene sample bottles and stored until analysis. Similar procedures were followed for the total soil As analysis, however, instead of a combined $\mathrm{HNO}_{3}$ and $\mathrm{H}_{2} \mathrm{SO}_{4}$ digestion, only $15 \mathrm{~mL}$ of Trace Metal Grade
$\mathrm{HNO}_{3}$ (Fisher Scientific) was used to digest the soil (Bounds 2001). The procedural blanks, consisting initially of $10 \mathrm{~mL}$ of Milli-Q water, were subjected to the same reagents to assess their potential as sources of As contamination during the digestion procedure.

Arsenic concentrations in the soil coal digests and bulk soil digests were measured by high-resolution inductively coupled plasma mass spectrometry (HRICP-MS; VG Axiom) at the Harry Reid Center for Environmental Studies, University of Nevada, Las Vegas (Dr. J. Cizdziel, analyst). The HR-ICP-MS was calibrated and the sample concentrations verified using a series of As calibration standards of known concentrations $(1,5,15,100 \mu \mathrm{g} / \mathrm{kg})$. The calibration standards were prepared from NIST traceable High Purity Standards (Charleston, SC). In addition, a check standard $(16.8 \mu \mathrm{g} / \mathrm{kg})$ was prepared from a Perkin Elmer As standard and analyzed regularly during the analyses to certify accuracy. Platinum was added to each sample prior to analysis as an internal standard to monitor for matrix effects, differences in sample viscosity, solute build-up on the sampler and skimmer cones, and instrument drift during the analyses (Guo 1996). Analytical precision was on the order of $5.9 \%$ relative standard deviation (RSD) for arsenic concentrations at $1 \mu \mathrm{g} / \mathrm{kg}$, and $3.1 \% \mathrm{RSD}$ at $100 \mu \mathrm{g} / \mathrm{kg}$ arsenic. The analytical precision of the check standards analyses was $2.2 \%$ RSD. Detection limits for As were $\sim 3 \mathrm{ng} / \mathrm{kg}$ using our approach, and As concentrations in procedural blanks were generally at or below detection (Bounds 2001).

\section{Results and Discussion}

\subsection{Soil Textual Classification}

Soils were matched to the Soil Survey of Norfolk County (i.e., Henry et al. 1959) based on color and textural classification. Texturally, all collected soil cores are sandy loams, and can be classified as belonging to the Woodstown, Sassafras, and Keyport soil types of Henry et al. (1959). Based on soil colors, seven samples including the Manchester Avenue $\left(\mathrm{N}_{1}\right)$, 37th Street $\left(\mathrm{N}_{2}\right)$, 35th Street $\left(\mathrm{N}_{3}\right)$, 39th Street $\left(\mathrm{N}_{5}\right)$, Silbert Road $\left(\mathrm{N}_{6}\right)$, Beckner Street $\left(\mathrm{N}_{7}\right)$, and the Dismal Swamp East $\left(\mathrm{DS}_{2}\right)$ belong to the Keyport soil type. The Princess Anne Road $\left(\mathrm{N}_{4}\right)$ and the Dismal Swamp West $\left(\mathrm{DS}_{1}\right)$ samples, however, fit the descrip- 
tion of the Woodstown soil type, whereas the Capeview Avenue $\left(\mathrm{N}_{8}\right)$ sample shares characteristics with the Sassafras soil (see Henry et al. 1959; Bounds 2001).

\subsection{Soil Separation Testing}

In order to establish the recovery efficiency of the extraction procedure used here to separate particulate coal from silicates, metal oxides, and organic matter in local soil samples (Section 3.2), the separation method was first applied to a simulated test soil sample containing a known amount of coal particles (see Bounds 2001 for details). Briefly, $9 \mathrm{~g}$ of sand and $1 \mathrm{~g}$ of crushed coal (collected from the Lambert's Point Docks) were mixed to create the test soil. Five separate aliquots from this test soil were then processed using the heavy liquid procedure described above in Section 3.2. Recoveries of coal particles from each of these test soil aliquots were 95, 81, 87, 84 , and $87 \%$, with a mean recovery ( \pm standard deviation) of $86 \pm 5.2 \%$ (Bounds 2001). The mean recovery indicates that the soil coal extraction method is relatively accurate, although it generally leads to an underestimate of the actual amount of particulate coal present in the soils. The underestimates may reflect some loss during the sodium polytungstate separation owing to sinking of coal particles containing heavy minerals like pyrite. Therefore, our estimates of the amount of particulate coal present in soils from Norfolk, Virginia likely err on the low side. The actual amount of particulate coal may exceed the estimates by as much as $17 \%$, on average (Bounds 2001).

Precision for the separation technique was quantified by using a second soil core collected from the Manchester Avenue site in Norfolk (location $\mathrm{N}_{1}$ ), and subjecting six different replicates of this soil sample to the heavy liquid separation procedure. The replicate analyses produced a relative standard error of \pm $8.46 \%$, indicating that the separation procedure produces relatively consistent results (i.e., better than \pm $10 \%$; Bounds 2001).

\subsection{Particulate Coal Distribution}

The distribution of coal (in wt.\%) in the soil cores and surface samples are presented in Tables 1 and 2, respectively. The surface soil samples (i.e., $\mathrm{S}_{1}$ through $\mathrm{S}_{15}$, Table 2), which were collected at depths of $4 \mathrm{~cm}$, are comparable to the shallowest samples from each soil core (Table 1). The amount of particulate coal that occurs in the surface soil samples (i.e., $4 \mathrm{~cm}$ depth) of the study area varies from a high of $\sim 20 \%$ by weight, to a low of 1 wt $\%$, exhibiting a mean value ( \pm standard deviation) of $7.1 \pm 3.9$ wt. $\%$. The surface sample $(4 \mathrm{~cm})$ from the 37 th Street core (i.e., $\mathrm{N}_{2}$ ) exhibits the highest amount of particulate coal (i.e., 19.9 wt. \%). The 37th Street core is located less than $1 \mathrm{~km}$ east of the Lambert's Point Docks (Fig. 1). The surface sample (4 cm depth) of the Silbert Road core $\left(\mathrm{N}_{6}\right)$, which is located approximately $5.5 \mathrm{~km}$ to the east of the Lambert's Point Docks (Fig. 1), has 3.4 wt. \% particulate coal, whereas the surface sample from the

Table 1 Amount of particulate coal (in weight \%) recovered from soil cores collected within Norfolk (N) and the Great Dismal Swamp (DS) in southeastern Virginia

\begin{tabular}{|c|c|c|c|c|c|c|c|c|c|c|}
\hline Depth $(\mathrm{cm})$ & $\mathrm{N}_{1}$ & $\mathrm{~N}_{2}$ & $\mathrm{~N}_{3}$ & $\mathrm{~N}_{4}$ & $\mathrm{~N}_{5}$ & $\mathrm{~N}_{6}$ & $\mathrm{~N}_{7}$ & $\mathrm{~N}_{8}$ & $\mathrm{DS}_{1}$ & $\mathrm{DS}_{2}$ \\
\hline 4 & 4.56 & 19.9 & 7.88 & 7.82 & 10 & 3.45 & 7.42 & 1.08 & 1.23 & 1.59 \\
\hline 8 & 2.2 & 20 & 7.29 & 7.22 & 9.84 & 3.95 & 6.72 & 0.83 & 1.33 & 1.47 \\
\hline 12 & 3.79 & 18.1 & 7 & 7 & 9.59 & 3.57 & 5.38 & 0.48 & 1 & 2.02 \\
\hline 16 & 3.75 & 16.2 & 6.87 & 6.87 & 8.33 & 3.55 & 5.57 & 0.68 & 1.31 & 1.74 \\
\hline 20 & 3.98 & 14 & 6.62 & 6.62 & 6.42 & 3.34 & 4.21 & 0.05 & 1.12 & 1.26 \\
\hline 24 & 3.03 & 10.4 & 5.91 & 5.91 & 6.15 & 2.78 & 3.1 & 0.01 & 1.29 & 1.63 \\
\hline 28 & 1.77 & 7.46 & 5.2 & 5.2 & 5.32 & 2.79 & 1.82 & 0.04 & 1.12 & 1.42 \\
\hline 32 & 2.12 & 8.82 & 4.64 & 4.64 & 3.88 & 3.88 & 1.56 & 0.05 & 1.07 & 1.59 \\
\hline
\end{tabular}

$N_{1}$ Manchester Avenue, $N_{2} 37$ th Street, $N_{3} 35$ th Street, $N_{4}$ Princess Anne Road, $N_{5} 39$ th Street, $N_{6}$ Silbert Road, $N_{7}$ Beckner Street, $N_{8}$ Capeview Avenue, $D S_{1}$ collected along the Washington Ditch in the Great Dismal Swamp ${ }^{\text {, }}$, and $D S_{2}$ collected at Arbuckle Landing, near the outflow of the Feeder Ditch ${ }^{\mathrm{a}}$

${ }^{\text {a }}$ See Johannesson et al. (2004). 
Table 2 Amount of particulate coal (in weight \%) recovered from surface samples (collected at $\sim 4 \mathrm{~cm}$ depth) from Norfolk, Virginia

\begin{tabular}{ll}
\hline & Weight \% coal \\
\hline $\mathrm{S}_{1}$ & 4.73 \\
$\mathrm{~S}_{2}$ & 5.36 \\
$\mathrm{~S}_{3}$ & 4.89 \\
$\mathrm{~S}_{4}$ & 6.07 \\
$\mathrm{~S}_{5}$ & 6.23 \\
$\mathrm{~S}_{6}$ & 7.03 \\
$\mathrm{~S}_{7}$ & 14.6 \\
$\mathrm{~S}_{8}$ & 7.49 \\
$\mathrm{~S}_{9}$ & 9.56 \\
$\mathrm{~S}_{10}$ & 8.93 \\
$\mathrm{~S}_{11}$ & 3.87 \\
$\mathrm{~S}_{12}$ & 4.82 \\
$\mathrm{~S}_{13}$ & 4.35 \\
$\mathrm{~S}_{14}$ & 3.77 \\
$\mathrm{~S}_{15}$ & 3.24 \\
\hline
\end{tabular}

Capeview Avenue core $\left(\mathrm{N}_{8}\right)$, roughly $12 \mathrm{~km}$ northeast of the docks, exhibits $1.1 \mathrm{wt} \%$ particulate coal (Table 1). The decrease in the amount of particulate coal within the surface soils with increasing distance from Lambert's Point Docks, and the fact that the prevailing wind direction for the region is from the west (Halpern et al. 2001), suggests that the docks are the chief source of particulate coal to these soils. Similar areal distribution patterns of particulate coal occur at depths in these soils (Bounds 2001). Soil samples collected proximal to the railroad tracks in the study region (e.g., $\mathrm{N}_{7}, \mathrm{~S}_{10}, \mathrm{~S}_{7}$, and $\mathrm{S}_{9}$ ) also exhibit relatively high particulate coal levels (Tables 1 and 2). These elevated soil coal levels indicate that coal cars transporting coal into the city along existing rail lines are also a source of particulate coal to local soils. Others have also recognized the importance of railway lines as sources of potential contaminants (Smith et al. 2006).

The amount of particulate coal in each soil core collected from the city of Norfolk (i.e., $\mathrm{N}_{1}$ through $\mathrm{N}_{8}$ ) decreases with increasing depth (Fig. 2). The decrease in particulate coal with depth is most evident for soil core $\mathrm{N}_{2}$, located less than a $\mathrm{km}$ from the Lambert's Point Docks (Figs. 1 and 2). For the Capeview Avenue core $\left(\mathrm{N}_{8}\right)$, the amount of particulate coal decreases from $\sim 1.1$ wt. $\%$ at a depth of $4 \mathrm{~cm}$ to below detection at $20 \mathrm{~cm}$, where it remains with increasing depth (to $32 \mathrm{~cm}$, Fig. 2, Table 1). The two soil cores from the Great Dismal Swamp $\left(\mathrm{DS}_{1}\right.$ and $\mathrm{DS}_{2}$ ) exhibit low, but constant amounts of particulate coal with depth (Fig. 2; Table 1). Both Great Dismal Swamp soil cores have amounts of particulate coal at the surface (i.e., $4 \mathrm{~cm}$ depth) that are comparable to the Capeview Avenue $\left(\mathrm{N}_{8}\right)$ core (1.23 and 1.59 wt. \% vs. 1.08 wt. $\%$, respectively), but have higher amounts of particulate coal at depth (Table 1, Fig. 2). The Great Dismal Swamp cores exhibit similar amounts of particulate coal at depth to the Manchester Avenue $\left(\mathrm{N}_{1}\right)$, Silbert Road $\left(\mathrm{N}_{6}\right)$, and Beckner Street $\left(\mathrm{N}_{7}\right)$ cores from within the city of Norfolk (Table 1; Fig. 2). Hence, the Great Dismal Swamp soil cores indicate that much of the Hampton Roads region of southeastern Virginia has experienced atmospheric deposition of particulate coal originating from the Lambert's Point Docks, or possibly other coal shipping docks in the region (e.g., Newport News, Virginia).

Assuming a uniform distribution of particulate coal in the surface soils equal to the mean amount of coal estimated from our soil core and surface samples (i.e., $4 \mathrm{~cm}$ depth, $7.1 \pm 3.9$ wt. $\%, n=22$ ), and an approximate bulk density for the soil of $1.9 \mathrm{~g} / \mathrm{cm}^{3}$ ( $\rho_{\text {solids }}=$ $2.65 \mathrm{~g} / \mathrm{cm}^{3}$ with porosity $\sim 30 \%$ ), the amount of particulate coal contained within the top $4 \mathrm{~cm}$ of the soils can be roughly estimated for the immediate study area (Norfolk south of the Lafayette River, north of the Eastern Branch of the Elizabeth River, and west of the railway line to the U.S. Naval Reservation; Fig. 1, $\sim 33 \mathrm{~km}^{2}$ ). These values lead to an estimate of $1.8 \times 10^{8}\left( \pm 10^{5}\right) \mathrm{kg}$ of particulate coal in the top $4 \mathrm{~cm}$ of soil within the immediate study area. It is important to stress that this estimate is severely compromised by the limited sample coverage in the study region and the assumption of a uniform distribution of coal, which the data demonstrate varies as a function of distance from the Lambert's Point Docks. Thus, the actual inventory of particulate coal in these soils could conceivable differ by orders of magnitude. It is noteworthy, however, that this rough, first approximation of the particulate coal inventory in Norfolk surface soils seems high compared to the permitted amount of particulate coal that the State of Virginia allows the Lambert's Point Docks to release annually (i.e., 50 tons: VDEQ (Virginia Department Environmental Quality) 2002). The estimate suggests that the our approach overstates the amount of particulate coal in Norfolk soils (laboratory experiments indicate, however, that the method under- 
Fig. 2 Concentrations, in weight percent, of particulate coal from a soil profiles resulting for the soil cores $\left(\mathrm{N}_{1}\right.$ through $\mathrm{N}_{8}, \mathrm{DS}_{1}$ and $\left.\mathrm{DS}_{2}\right)$, and $\mathbf{b}$ the surface soil samples $\left(\mathrm{S}_{1}\right.$ through $\left.\mathrm{S}_{15}\right)$. The surface samples are included in panel a but are reproduced in panel $\mathbf{b}$ for clarity

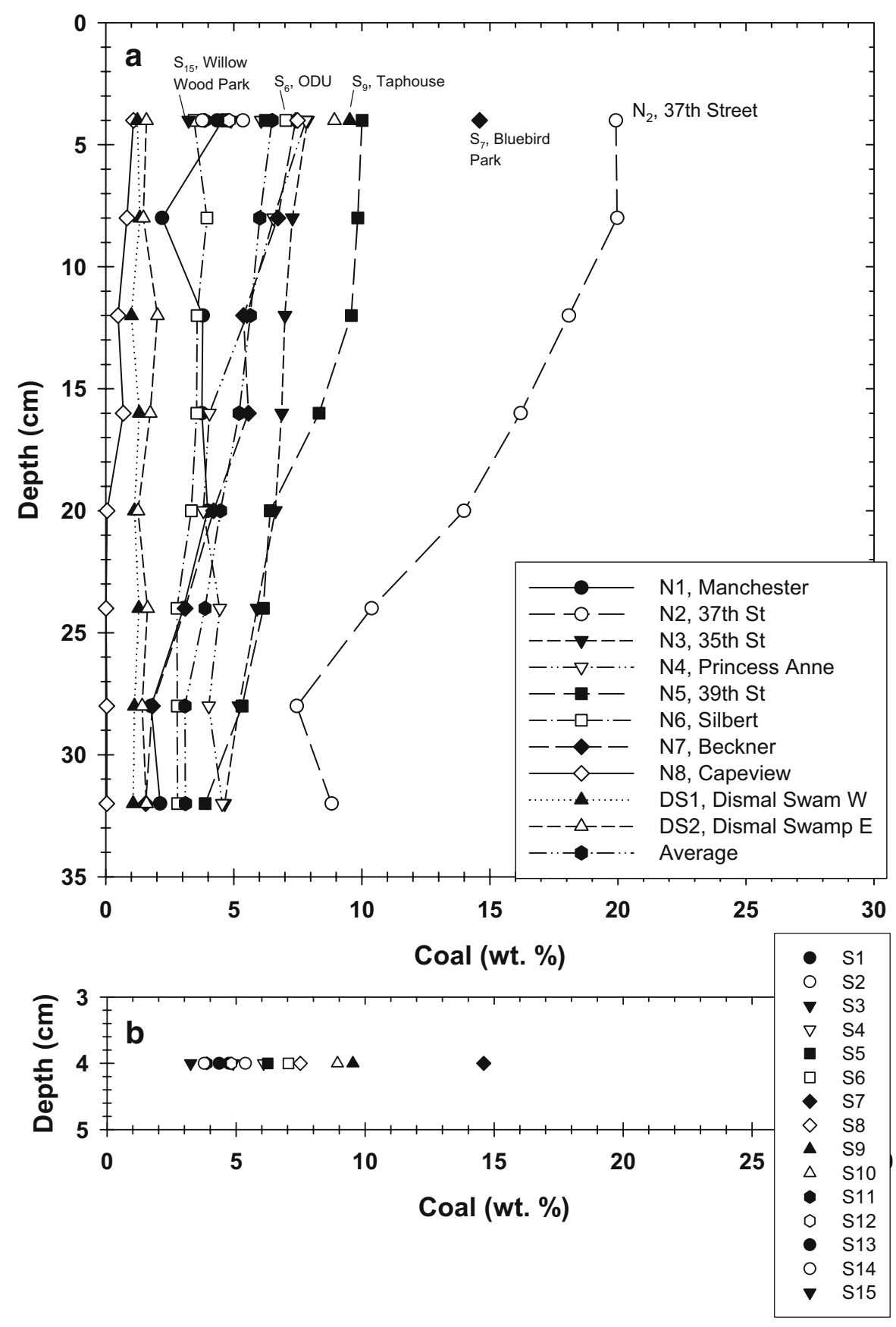

estimates the amount of coal present, Section 4.2), that other sources of particulate coal dust, such as the coal shipping terminal in nearby Newport News, Virginia, local railway lines, etc., contribute coal dust to Norfolk soils, and/or that the Lambert's Point Dock commonly exceeds its permitted release levels of particulate coal to the atmosphere. Clearly, more study of the fluxes of particulate coal in the Hampton Roads region of Virginia is warranted to better constrain the sources and mass balance of particulate coal.

\subsection{Soil Arsenic Concentrations}

Coal shipped to and from the Lambert's Point Docks originates from mines in Alabama, Indiana, Illinois, Kentucky, Tennessee, Ohio, Pennsylvania, Virginia, 
and West Virginia (Norfolk Southern 2007). Coal from these states, which are located within the Appalachian and Eastern Interior coal basins, have As concentrations that range, on average, from 20 to $70 \mathrm{mg} / \mathrm{kg}$ (Kolker et al. 2006; Mastalerz and Drobniak 2007; and references therein). The mean As concentration of coal from Virginia is $20.2 \mathrm{mg} / \mathrm{kg}$ (Henderson et al. 1985; Hower et al. 1997). These mean values are between an order of magnitude to as much as $\sim 45$ times greater than upper continental crust As concentrations (1.5-2.0 mg/kg; Taylor and McLennan 1985; Wedepohl 1995). Hence, because of the relatively high As concentrations that characterize some coal from the Appalachian and Eastern Interior coal basins, we chose to evaluate whether the particulate coal dispersed to Norfolk soils has enriched As in these soils.

Arsenic values for the sand-sized coal particles extracted from cores $\mathrm{N}_{1}$ through $\mathrm{N}_{7}$ range from a high of $17.4 \mathrm{mg} / \mathrm{kg}$ at $8 \mathrm{~cm}$ depth within the 37 th Street core $\left(\mathrm{N}_{2}\right)$, to below detection (i.e., $<3 \mathrm{ng} / \mathrm{kg}$ ) at $16 \mathrm{~cm}$ and $32 \mathrm{~cm}$ depths within the Silbert Road core $\left(\mathrm{N}_{6}\right.$; Fig. 3; Table 3). Because no sand-sized coal particles were recovered from the Capeview Avenue core $\left(\mathrm{N}_{8}\right)$, or the Great Dismal Swamp cores $\left(\mathrm{DS}_{1}, \mathrm{DS}_{2}\right)$, we did not determine the coal-dust associated As in these cores using the methods employed in this study. Nonetheless, the mean As concentration for sandsized coal particles collected from all depths in cores $\mathrm{N}_{1}$ through $\mathrm{N}_{7}$ is $7.3 \mathrm{mg} / \mathrm{kg}$.
Fig. 3 Concentrations of arsenic in $\mathrm{mg} / \mathrm{kg}$ in sandsize coal particles separated from soil core samples collected at $8,16,24$, and $32 \mathrm{~cm}$ depth

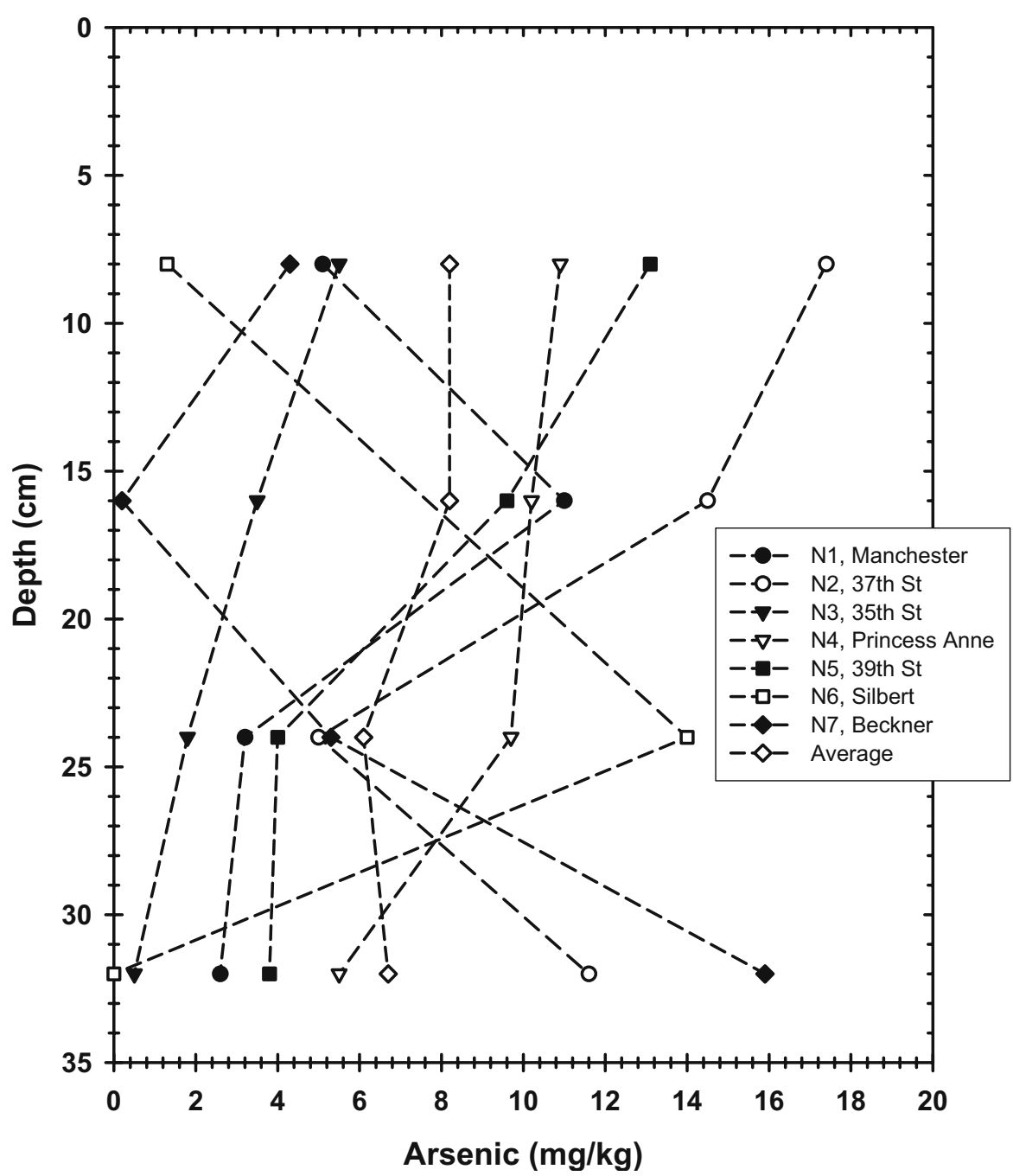


Table 3 Arsenic concentrations (in $\mathrm{mg} / \mathrm{kg}$ ) of sand-sized particulate coal recovered from soil cores collected from Norfolk, Virginia ${ }^{\mathrm{a}}$

\begin{tabular}{lllllllllll}
\hline Depth (cm) & $\mathrm{N}_{1}$ & $\mathrm{~N}_{2}$ & $\mathrm{~N}_{3}$ & $\mathrm{~N}_{4}$ & $\mathrm{~N}_{5}$ & $\mathrm{~N}_{6}$ & $\mathrm{~N}_{7}$ & Mean & Max \\
\hline 8 & 5.1 & 17.4 & 5.5 & 10.9 & 13.1 & 1.3 & 4.3 & 8.2 & 17.4 \\
16 & 11 & 14.5 & 3.5 & 10.2 & 9.6 & $\mathrm{BD}$ & 0.2 & 8.2 & 1.3 \\
24 & 3.2 & 5 & 1.8 & 9.7 & 4 & 14 & 5.3 & 6.1 & 14 \\
32 & 2.6 & 11.6 & 0.5 & 5.5 & 3.8 & $\mathrm{BD}$ & 15.9 & 6.7 & 1.9 \\
\hline
\end{tabular}

${ }^{\text {a }}$ No sand-sized particulate coal was recovered from N8, DS1, or DS2, hence, we did not analyze this absent coal size fraction for As. $B D$ below detection

Arsenic concentrations of sand-sized coal particles from Norfolk soil cores are all lower than the mean As values reported for coal from the Appalachian and Eastern Interior coal basins (Kolker et al. 2006), as well as the average As concentration reported for Virginia coals (i.e., $20.2 \mathrm{mg} / \mathrm{kg}$; Henderson et al. 1985). We expect that the As concentration of the sand-sized coal particles recovered from Norfolk soils to generally be lower than bulk coal samples from the Appalachian and Eastern Interior coal basin owing to: (1) selective mining that extracts low As coals; (2) coal cleaning that can reduce As in coal by as much as 50\%; (3) physical separation of As-bearing pyrite during transport and shipping; and (4) possible loss of some As-rich coal particles during our laboratory separations where denser pyrite containing particles may sink (R.B. Finkelman, 2007, personal communication). Nevertheless, As concentrations of sand-sized coal particles recovered from Norfolk soils are similar to those measured in coals samples $(n=3)$ obtained from the Lambert's Point Docks (i.e., $12.6 \mathrm{mg} / \mathrm{kg}$; Bounds 2001). Arsenic concentrations measured in sand-sized particulate coal from the Norfolk soil core samples are, therefore, enriched by 4-5 times, on average, over that of the upper continental crust.

A recent survey of As levels in surficial deposits (i.e., soils and sediments) of North America indicates that background As concentrations range from crustal values $(1-2 \mathrm{mg} / \mathrm{kg}$ ) up to $\sim 7 \mathrm{mg} / \mathrm{kg}$ in soil/sediments of southeastern Virginia, with the highest levels centered in Norfolk (Grosz et al. 2004). These preliminary data suggest that background As concentrations in soils/ sediments from the Norfolk region are, to a first approximation, similar to average soil As concentrations in the USA (e.g., 5-7 mg/kg; Shacklette and Boerngen 1984; Yang and Donahoe 2007). However, the observation that directly to the west of the city of Norfolk, the background surficial As concentrations drop to crustal or lower values from a high of $\sim 7 \mathrm{mg} / \mathrm{kg}$ within the city center (Grosz et al. 2004), supports the hypothesis that coal shipping through the Lambert's Point Docks is at least partially responsible for elevating soil zone As concentrations within the city.

Arsenic concentrations for the total (i.e., bulk) soil digests (silicate minerals, metal oxides, amorphous phases, organic matter, and particulate coal), performed on aliquots from $8 \mathrm{~cm}$ depth for each soil core, ranged from a high of $30.5 \mathrm{mg} / \mathrm{kg}$ to a low of $3.0 \mathrm{mg} / \mathrm{kg}$, with a mean As value of $13.3 \mathrm{mg} / \mathrm{kg}$ (Table 4). The total soil digests indicate that Norfolk soils (from a depth of $8 \mathrm{~cm}$ ) are enriched in As by a factor of 2 to 20 times over upper continental crustal abundances (Taylor and McLennan 1985; Wedepohl 1995), and by as much as five times over background soil concentrations (Shacklette and Boerngen 1984; Grosz et al. 2004; Yang and Donahoe 2007). Therefore, it can be inferred from these data that a substantial amount of the total As in Norfolk soils (at $8 \mathrm{~cm}$ depths) reflects the presence of sand-sized, particulate coal in these soils (Fig. 4). More specifi-

Table 4 Arsenic concentrations (in $\mathrm{mg} / \mathrm{kg}$ ) of total soil digests of soil samples collected from $8 \mathrm{~cm}$ depth in each soil core from the study region

\begin{tabular}{ll}
\hline & As $(\mathrm{mg} / \mathrm{kg})$ \\
\hline $\mathrm{N}_{1}$ & 8.1 \\
$\mathrm{~N}_{2}$ & 16.6 \\
$\mathrm{~N}_{3}$ & 7.8 \\
$\mathrm{~N}_{4}$ & 20.7 \\
$\mathrm{~N}_{5}$ & 30.5 \\
$\mathrm{~N}_{6}$ & 3 \\
$\mathrm{~N}_{7}$ & 12.1 \\
$\mathrm{~N}_{8}$ & 25.9 \\
$\mathrm{DS}_{1}$ & 3.2 \\
$\mathrm{DS}_{2}$ & 5.1 \\
Mean & 13.3 \\
Max & 30.5 \\
Min & 3 \\
\hline
\end{tabular}


Fig. 4 Percent of soil arsenic that can be attributed to particulate coal within the sand-size fractions of the $8 \mathrm{~cm}$ depth samples of soil cores $\mathrm{N}_{1}$ through $\mathrm{N}_{7}$, plotted as a function of relative distance from Lambert's Point Docks. In addition, the mean value is also shown. Note there is a general decrease in the percentage of As in these samples that can be ascribed to particulate coal as distance increases away from the Lambert's Point Docks

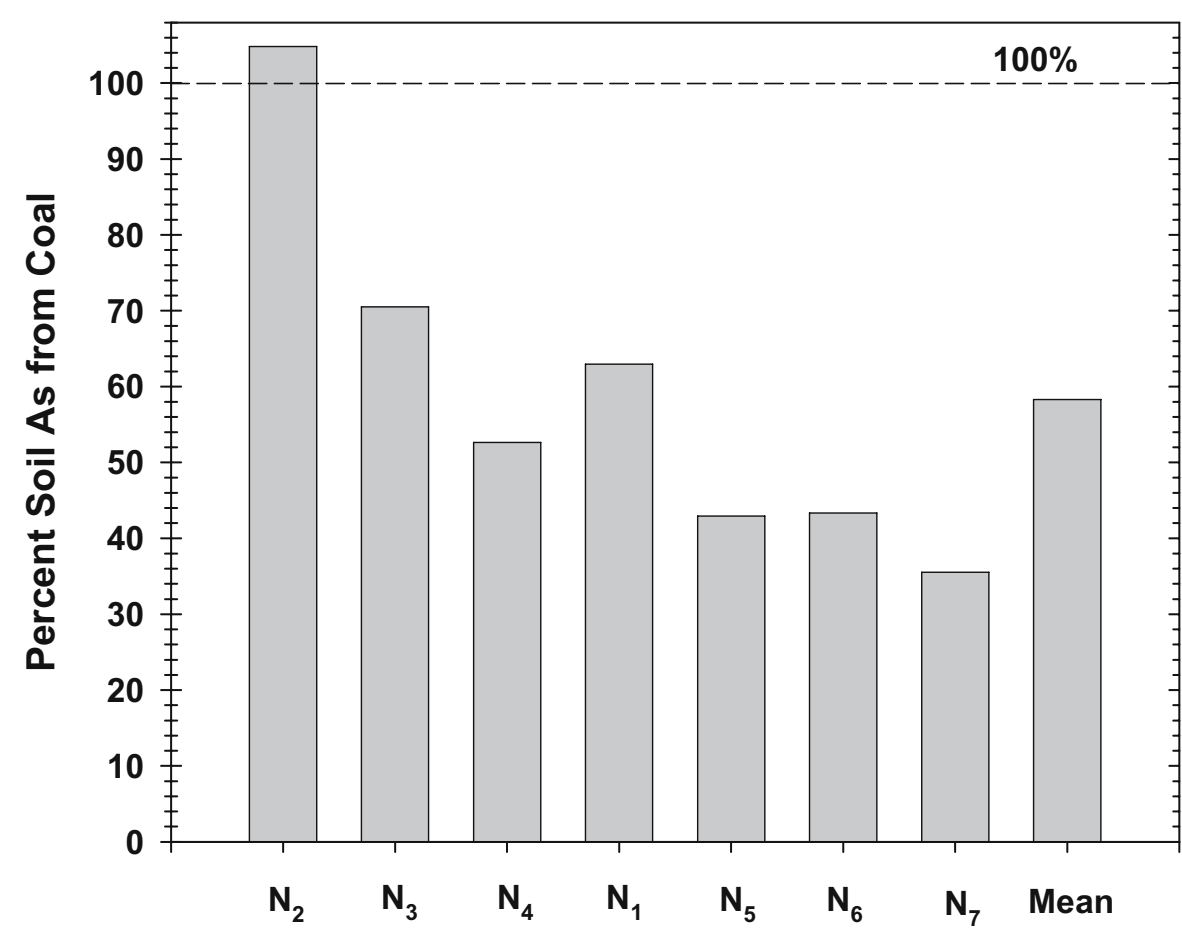

cally, the amount of As in these soils from $8 \mathrm{~cm}$ depth that owes its origin to sand-sized coal particles ranges from $\sim 36 \%$ for the Beckner Street $\left(\mathrm{N}_{7}\right)$ sample up to $\sim 100 \%$ for the 37 th Street core $\left(\mathrm{N}_{2}\right)$, with an overall mean of $\sim 58 \%$ (Table 4; Fig. 4). Another important feature of the percentage of As in these soil core samples that is attributable to particulate coal is that this percentage generally decreases with distance from the Lambert's Point Docks (Fig. 4). Note that essentially all of the As within the $8 \mathrm{~cm}$ sample from the 37th Street core $\left(\mathrm{N}_{2}\right)$, which is located within $1 \mathrm{~km}$ of the Lambert's Point Docks, can be attributed to particulate coal, whereas only $\sim 36 \%$ of the As from the $8 \mathrm{~cm}$ sample of the Beckner Street core $\left(\mathrm{N}_{7}\right)$, approximately $5.5 \mathrm{~km}$ from the Docks, can be ascribed to particulate coal. Thus, particulate coal originating from Lambert's Point Dock is an important source of As to the local soils, especially for soils located in close proximity to the Docks.

Because we have only analyzed As in sand-sized coal particles extracted from the soil samples, and owing to the fact that our soil-coal separation techniques tends to underestimate the amount of coal dust in the soils (Section 4.1), the actual percentage of As in these soils due to particulate coal originating from Lambert's Point Docks may be higher than indicated in Fig. 4. Nevertheless, these data suggest that coal shipping through the Lambert's Point Docks is adding particulate coal and As to the soils of Norfolk, Virginia. The significance of this additional As to human and/or environmental health in southeastern Virginia is currently unknown. However, application of phosphorous-rich fertilizers to these soils, many of which are overlain by lawns, could potentially lead to the mobilization of the added As in Norfolk soils (e.g., Peryea and Kammereck 1997). Furthermore, a recent study demonstrated that children playing in playgrounds with chromated copper arsenate treated wooden playground structures or with sand that has come in contact with such structures, acquire more soluble As on their hands compared to children not exposed to such structures or the associated sand (Kwon et al. 2004). Moreover, children that live near open-pit coal mines more frequently complain of respiratory distress to family physicians than children living more distal to such operations (Howel et al. 2001; Moffatt and Pless-Mulloli 2003). Hence it seems reasonable to investigate more fully the possible health effects of particulate coal and associated As, if any, on the local populace of Hampton Roads. Finally, on a related topic, Reidel et al. (2000) presents data that strongly suggests that meteoric water interacting with standing coal piles in the region can significantly increase the As loading to 
local surface water bodies. Further investigation of Norfolk's groundwater, as well as the estuarine waters surrounding the city, may shed additional light on the potential impact of particulate coal derived As on these waters and the local environment.

\section{Conclusions}

Substantial amounts of particulate coal originating from the Lambert's Point Docks are documented in soil samples from Norfolk, Virginia, with regions closest to the shipping terminal containing the most particulate coal by weight. Along with the particulate coal, arsenic associated with the coal is also enriched in these soils by 2 to 20 times over upper crustal abundances, and by $\sim$ five times over estimated background soil As concentrations. The data presented here indicate that the Lambert's Point Docks is a significant source of particulate coal to the local environment, and further, that this coal contributes As to the local soils.

Acknowledgements The authors wish to thank Drs. J. Sanders and J. Rule for reading an earlier version of this manuscript and providing important and helpful input for this project. We are also especially grateful to Drs. K. Stetzenbach and J. Cizdziel of the Harry Reid Center (HRC) for Environmental Studies at the University of Nevada, Las Vegas for arranging and performing the arsenic analyses. We wish to thank N. McGinnis and J. Daniels, also at the HRC, for helping with the soil sample collection, and S. Haque and M. Vessely (The University of Texas at Arlington) for editorial assistance. The Department of Ocean, Earth, and Atmospheric Sciences at Old Dominion University, the Commonwealth of Virginia, and the American Association of Petroleum Geologists provided funding for the project. We thank J. Quintans of The University of Texas at Arlington Office of University Publications for drafting the map. Finally, we express our gratitude to R.B. Finkelman and two anonymous reviewers whose comments greatly improved this manuscript.

\section{References}

Attfield, M., Kuempel, E., \& Wagner, G. (1997). Exposureresponse for coal workers' pneumoconiosis in underground coal miners: A discussion of issues and findings. The Annals of Occupational Hygiene, 41(Suppl. 1), 341-345.

Attfield, M. D., Petsonk, E. L., \& Wagner, G. R. (1998). Coal workers' lung diseases. In J. M. Stellman (Ed.), Encyclopaedia of occupational health and safety (4th ed., pp. 10.46-10.50). Geneva: International Labor Office.

Brady, N. C., \& Weil, R. R. (1996). The nature and properties of soils. Upper Saddle River, NJ: Prentice-Hall.
Bounds, W. J. (2001). The distribution of airborne coal dust in soil profiles of Norfolk, VA and its implications for arsenic loading to these soils. MS thesis. Virginia: Old Dominion University.

Centeno, J. A., Mullick, F. G., Ishak, K. G., Franks, T. J., Burke, A. P., Koss, M. N., et al. (2005). Environmental pathology. In O. Selinus, B. J. Alloway, J. A. Centeno, R. B. Finkelman, R. Fuge, U. Lindh, et al. (Eds.), Essentials of medical geology: Impacts of the natural environment on public health (pp. 563-594). Amsterdam: Elsevier.

Dinsmore, C. (1999). Loads of coal Norfolk southern terminal marks its 1 billionth ton. Norfolk, VA: The Virginian-Pilot, September 4, D1.

Eskenazy, G. M. (1995). Geochemistry of arsenic and antimony in Bulgarian coals. Chemical Geology, 119, 239-254.

Feng, X., Hong, Y., Hong, B., \& Ni, J. (2000). Mobility of some potentially toxic trace elements in the coal of Guizhou, China. Environmental Geology, 39, 372-377.

Finkelman, R. B., Belkin, H. E., \& Centeno, J. A. (2006). Health impacts of coal: Should we be concerned? Geotimes, 51, 24-28.

Finkelman, R. B., Orem, W., Castranova, V., Tatu, C. A., Belkin, H. E., Zheng, B., et al. (2002). Health impacts of coal and coal use: Possible solutions. International Journal of Coal Geology, 50, 425-443.

Fuge, R. (2005). Anthropogenic sources. In O. Selinus, B. J. Alloway, J. A. Centeno, R. B. Finkelman, R. Fuge, U. Lindh, et al. (Eds.), Essentials of medical geology: Impacts of the natural environment on public health (pp. 43-60). Amsterdam: Elsevier.

Gee, G. W., \& Bauder, J. W. (1986). Particle size analysis. Methods of soil analysis, Part 1. Physical Mineralogical, 9, 383-411.

Greb, S. F., Eble, C. F., Peters, D. C., \& Papp, A. R. (2006). Coal and the environment (p. 64). Alexandria, Virginia: AGI Environmental Awareness Series, American Geological Institute.

Grosz, A. E., Grossman, J. N., Garrett, R., Friske, P., Smith, D. B., Darnley, A. G., et al. (2004). A preliminary geochemical map of arsenic in surficial materials of Canada and the United States. Applied Geochemistry, 19, 257-260.

Guo, C. (1996). Determination of fifty-six elements in three distinct types of geological materials by inductively coupled plasma-mass spectrometry. MS thesis, Nevada: University of Nevada, Las Vegas.

Gupta, D. C. (1999). Environmental aspects of selected trace elements associated with coal and natural waters of Pench Valley Coalfield of India and their impact on human health. International Journal of Coal Geology, 40, 133149.

Halpern, D., Woiceshy, P. M., Zlotnicki, V., Brown, O. B., Feldman, G. C., Freilich, M. H., et al. (2001). An atlas of monthly mean distribution of SSMI surface wind speed, A VHRR sea surface temperature, TNI sea surface temperature, AMI surface wind velocity, Sea WiFS Chlorophyll-a, and TOPEX/POSEIDON sea surface topography during 1999. Pasadena, California: Jet Propulsion Laboratory.

Henderson, J. A. Jr., Wilkes, G. P., Bragg, L. J., \& Oman, C. L. (1985). Analyses of Virginia coal samples collected 19781980. Charlottesville, Virginia: Virginia Division of Mineral Resources, Publication 63. 
Henry, E. F., Chudoba, J., Porter, H. C., \& Ligon, W. S. (1959). Soil survey. Norfolk County Virginia: United States Department of Agriculture.

Howel, D., Pless-Mulloni, T., \& Darnell, R. (2001). Consultations of children living near open-cast coal mines. Environmental Heath Perspectives, 109, 567-571.

Hower, J. C., Robertson, J. D., Wong, A. S., Eble, C. F., \& Ruppert, L. F. (1997). Arsenic and lead concentrations in the pond creek and fire clay coal beds, eastern Kentucky coal field. Applied Geochemistry, 12, 281-289.

Johannesson, K. H., Tang, J., Daniels, J. M., Bounds, W. J., \& Burdige, D. J. (2004). Rare earth element concentrations and speciation in organic-rich blackwaters of the Great Dismal Swamp, Virginia, USA. Chemical Geology, 209, 271-294.

Kizilshtein, L. Y., \& Kholodkov, Y. I. (1999). Ecologically hazardous elements in coal of the Donets Basin. International Journal of Coal Geology, 40, 189-197.

Kolker, A., Palmer, C. A., Bragg, L. J., \& Bunnell, J. E. (2006). Arsenic in coal. U.S. Geological Survey Fact Sheet, 20053152.

Kwon, E., Zhang, H., Wang, Z., Jhangri, G. S., Lu, X., Fok, N., et al. (2004). Arsenic on the hands of children after playing in playgrounds. Environmental Health Perspectives, 112, 1375-1380.

Lewis, D. W., \& McConchie, D. (1994). Analytical sedimentology. New York: Chapman \& Hall.

Mastalerz, M., \& Drobniak, A. (2007). Arsenic, cadmium, lead, and zinc in the Danville and Springfield coal members (Pennsylvanian) from Indiana. International Journal of Coal Geology, 71, 37-53.

Mixon, R. B., Berquist, C. R., Newell, W. L., Johnson, G. H., Powars, D. S., Schindler, J. S., et al. (1989). Geologic map and generalized cross sections of the Coastal Plain and adjacent parts of the Piedmont Virginia. Washington, DC: US Geological Survey.

Moffatt, S., \& Pless-Mulloli, T. (2003). It wasn't the plague we expected. Parents' perceptions of the health and environmental impact of opencast coal mining. Social Science \& Medicine, 57, 437-451.

Norfolk Southern Corporation (2007). Website accessed 1 May 2007 http://www.nscorp.com/nscportal/nscorp/Customers/ Coal/Mine\%20Operations/index.html).

Peryea, F. J., \& Kammereck, R. (1997). Phosphate-enhanced movement of arsenic out of lead arsenate-contaminated topsoil and through uncontaminated subsoil. Water, Air, \& Soil Pollution, 93, 243-254.

Querol, X., Alastuey, A., Lopez-Soler, A., Plana, F., Mantilla, E., Juan, R., et al. (1999). Characterisation of atmospheric particulates around a coal-fired power station. International Journal of Coal Geology, 40, 175-188.

Querol, X., Fernandez, J. L., Lopez, A., \& Duran, M. E. (1992). Trace elements in high-S subbituminous coals from the Teruel Mining District, northeast Spain. Applied Geochemistry, 7, 547-561.

Querol, X., Fernandez, J. L., Lopez, A., Hagemann, H. W., Dehmer, J., Juan, R., et al. (1991). Distribution of sulfur in coals of the Teruel Mining District, Spain. International Journal of Coal Geology, 18, 327-346.

Riedel, G. F., Williams, S. A., Reidel, G. S., Gilmour, C. C., \& Sanders, J. G. (2000). Temporal and spacial patters of trace elements in the Patuxent River: A whole watershed approach. Estuaries, 23, 521-535.

Shacklette, H. T., \& Boerngen, J. G. (1984). Element concentrations in soils and other surficial materials of the conterminous United States. U.S. Geological Survey Professional Paper 1270.

Smith, E., Naidu, R., \& Alston, A. M. (1998). Arsenic in the soil environment: A review. Advances in Agronomy, 64, 149-195.

Smith, E., Smith, J., \& Naidu, R. (2006). Distribution and nature of arsenic along former railway corridors of South Australia. Science of the Total Environment, 363, 175-182.

Taylor, S. R., \& McLennan, S. M. (1985). The continental crust: Its composition and evolution. Boston: Blackwell Scientific Publications.

VDEQ (Virginia Department Environmental Quality) (2002). http://www.deq.state.va.us/.

Wedepohl, K. H. (1995). The composition of continental crust. Geochimica et Cosmochimica Acta, 59, 1217-1232.

Yang, L., \& Donahoe, R. J. (2007). The form, distribution and mobility of arsenic in soils contaminated by arsenic trioxide, at sites in southeast USA. Applied Geochemistry, 22, 320-341.

Yudovich, Ya. E., \& Ketris, M. P. (2005). Arsenic in coal: A review. International Journal of Coal Geology, 61, 141-196.

Zheng, B., Ding, Z., Haung, R., Zhu, J., Yu, X., Wang, A., et al. (1999). Issues of health and disease related to coal use in southwestern China. International Journal of Coal Geology, 40, 119-132. 